Katarzyna Bańkowska Jakub Jasiński

\title{
Ocena potencjału towarowości gospodarstw ekologicznych - na przykładzie województwa podlaskiego
}

Streszczenie: Społeczeństwo europejskie gwałtownie rozwija swoje zainteresowania dotyczące ochrony środowiska. Przekłada się to na przemiany postaw konsumpcyjnych. Świadomi konsumenci, poszukujący żywności dobrej jakości, przywiązują wagę do przejrzystości systemu jej produkcji oraz interesują się jej pochodzeniem. Rolnictwo ekologiczne i jego produkty stanowią jedną z możliwych odpowiedzi na rodzące się i dynamicznie rozwijające się trendy konsumpcyjne.

W dyskusjach nad przyszłością rolnictwa ekologicznego częstym tematem jest kwestia dedykowanego sektorowi bio(eko)wsparcia. Gospodarstwa prowadzone metodami ekologicznymi z jednej strony przyczyniają się do wytwarzania środowiskowych dóbr publicznych, z drugiej strony są miejscem produkcji wysokiej jakości żywności. Zasadne staje się nie tylko analizowanie dynamiki zmian areału upraw ekologicznych oraz liczby podmiotów posiadających stosowny certyfikat, ale przede wszystkim potencjału produkcyjnego tego sektora. Autorzy niniejszego tekstu opracowali metodę pozwalającą w stosunkowo prosty sposób i przy użyciu dotychczas wykorzystywanego narzędzia (FADN ang. Farm Accountancy Data Network, pol. System Zbierania i Wykorzystywania Danych Rachunkowych z Gospodarstw Rolnych) szacować potencjał ekologicznej produkcji i jej specjalizacji na określonym obszarze.

Słowa kluczowe: rolnictwo ekologiczne, wielkość produkcji w gospodarstwach ekologicznych, ekologiczny potencjał produkcyjny.

„Rolnictwo ekologiczne łączy tradycję, innowacje i naukę, przynosząc korzyści wspólnemu środowisku i promując uczciwe relacje oraz dobrą jakość życia wśród

Dr Katarzyna Bańkowska, Instytut Rozwoju Wsi i Rolnictwa PAN, Zakład Modelowania Ekonomicznego, ul. Nowy Świat 72, 00-330 Warszawa, katarzyna.bankowska@irwirpan.waw.pl, ORCID: 0000-0002-89320136; dr Jakub Jasiński, Instytut Rozwoju Wsi i Rolnictwa PAN, Zakład Integracji Europejskiej, ul. Nowy Świat 72, 00-330 Warszawa, kuba.jasinski@gazeta.pl, ORCID: 0000-0002-9964-7167. 


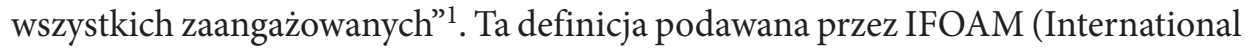
Federation of Organic Agriculture Movements - Organics International) nie podejmuje jednej ważnej kwestii - powiązania rolnictwa ekologicznego z rynkiem. Uwzględnienie powiązań rynkowych jest niezmiernie ważne, gdyż z jednej strony pozwala na zwiększenie społecznej akceptowalności dla wszelkiego wsparcia udzielanego temu sektorowi, z drugiej strony samo wsparcie udzielane gospodarstwom ekologicznym winno przekładać się na wzrost podaży produktów ekologicznych i tym samym - poprzez obniżkę cen - zwiększać dostępność tych produktów dla statystycznego obywatela (Nowogródzka, Podstawka, Szarek 2013). Istotne jest zatem opracowanie metody szacowania, na ile prężnie rozwijający się sektor rolnictwa ekologicznego w Polsce ma potencjał produkcji towarowej.

\section{Sytuacja rolnictwa ekologicznego w Polsce}

Po okresie dynamicznego rozwoju w okresie 2004-2013 w Polsce w kolejnych latach zaobserwowano lekki spadek liczby ekologicznych producentów rolnych oraz zmniejszenie powierzchni użytków ekologicznych (względem liczby certyfikowanych gospodarstw ekologicznych ewidencjonowanych w 2013 r.).

Powodem tego stanu rzeczy były zmiany przepisów dotyczących dofinansowania udzielanego producentom stosującym ekologiczne metody produkcji (Golik, Żmija 2017; Styczek-Kuryluk 2016). Intencją prawodawców było najczęściej ograniczenie możliwości ewentualnych nadużyć i nieuczciwych praktyk, do których skłaniały wyższe od stosowanych w konwencjonalnym rolnictwie dopłaty, a które nagłaśniane w mediach podważały wiarygodność osób autentycznie zaangażowanych w ideę ekologicznej produkcji żywności (zob. Lisowska 2010; Śmigiel, Miączyński, Kostrzewski 2009). Rok 2013 był to także czas, gdy kończyło się wsparcie dla gospodarstw ekologicznych finansowane z perspektywy WPR (Wspólnej Polityki Rolnej) 2007-2013, a jeszcze nie rozpoczęło się to pochodzące z perspektywy 2014-2020 - co przy dużym „uzależnieniu” rolnictwa ekologicznego od dopłat wspólnotowych (Brodzińska 2014) musiało skutkować częściowym odejściem rolników z systemu.

Trwające dyskusje na temat przyszłości wsparcia producentów ekologicznych dotyczą głównie kwestii powiązania systemu dopłat $\mathrm{z}$ faktem dostarczania produktów na rynek ${ }^{2}$ oraz wzmocnienia pozycji rolników w łańcuchu dostaw żywności (Komisja Europejska 2016; MRiRW 2018). Podatnicy zainteresowani są bowiem

\footnotetext{
1 IFOAM; https://www.ifoam.bio/en/organic-landmarks/definition-organic-agriculture, 25.10.2017.

2 Ryszard Zarudzki, za http://www.portalspozywczy.pl/technologie/wiadomosci/ministerstwo-rolnictwa-bedzie-wspieralo-rolnictwo-ekologiczne,166003.html (dostęp: 11.06.2019).
} 


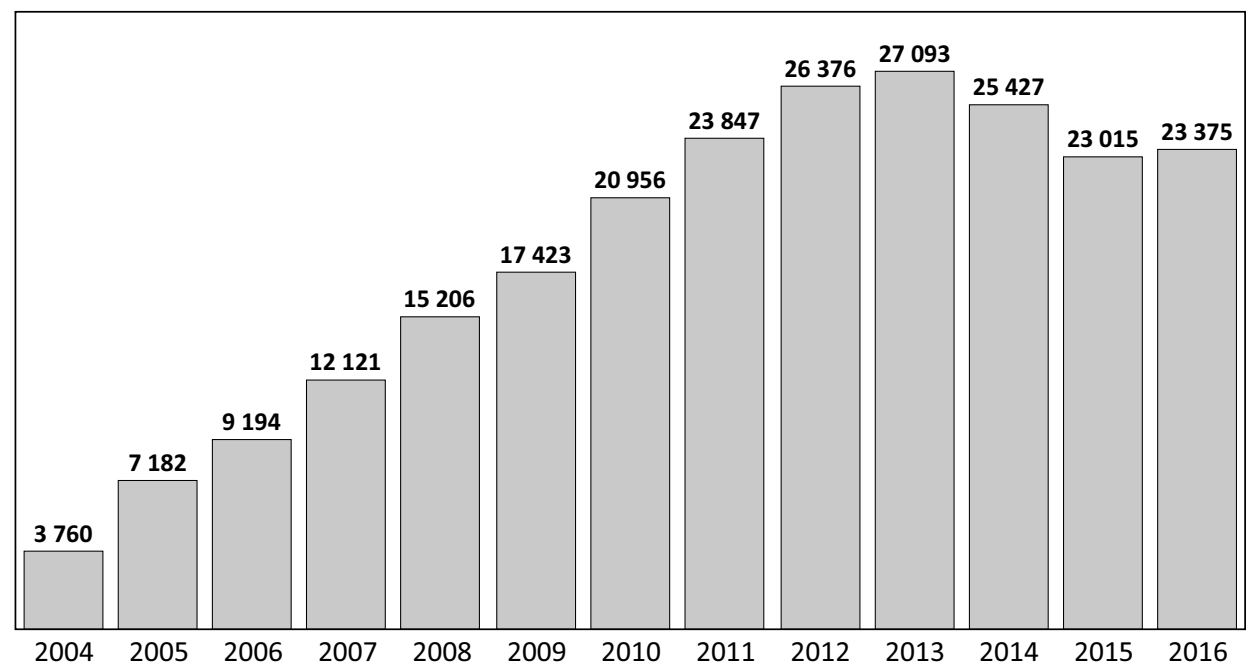

Rysunek 1. Dynamika liczby producentów ekologicznych w Polsce w latach 2004-2016 Figure 1. Change in the number of organic producers in Poland 2004-2016

Źródło: GIJHARS 2017.

Source: GIJHARS 2017.

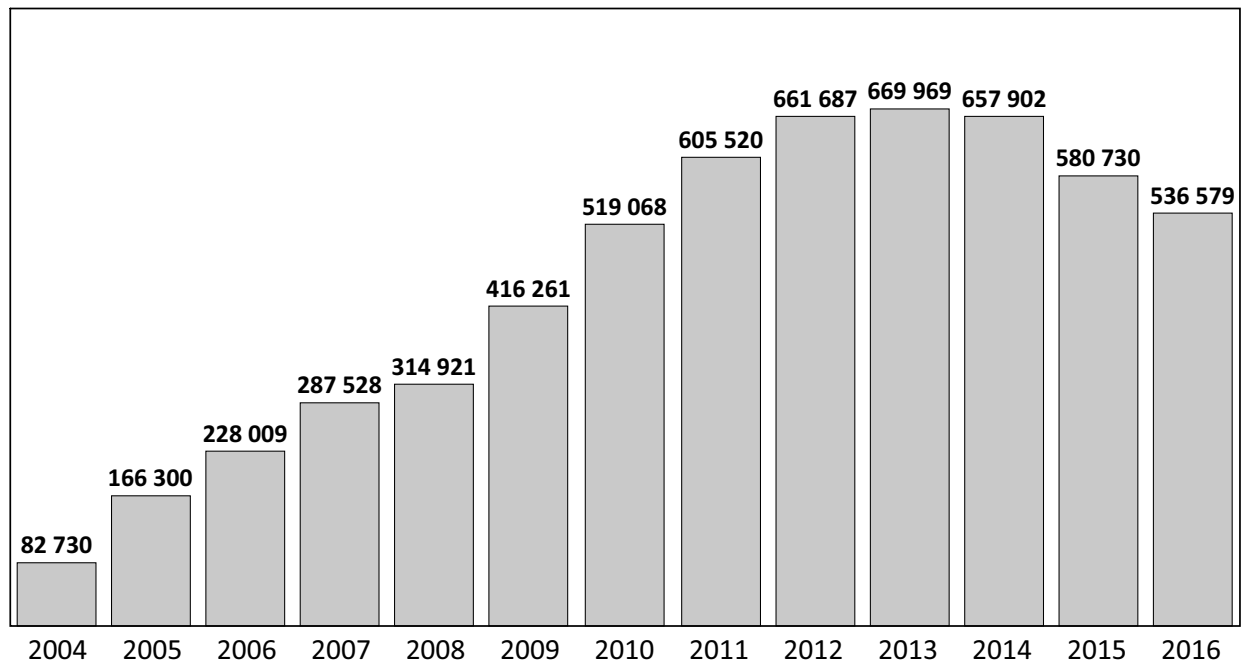

Rysunek 2. Dynamika powierzchni ekologicznych użytków rolnych w Polsce w latach 2004-2016 (w ha)

Figure 2. Change in the area of organic agricultural land in Poland 2004-2016 (in ha)

Źródło: GIJHARS 2017.

Source: GIJHARS 2017. 
w większym stopniu wspomaganiem gospodarstw, które faktycznie mają związki z konsumentami (EKES 2017; EKR 2017), niż wspomaganiem gospodarstw, które nie wykazują związków z rynkiem (Poczta i in. 2017). Jak pokazują wyniki prowadzonych badań (Drygas i in. 2017), pożądanym rozwiązaniem mogłoby być stworzenie równoległego systemu wsparcia, który poza dopłatami do praktyk przyjaznych środowisku dodatkowo dotowałby te gospodarstwa, które nie tylko przyczyniają się do poprawy stanu środowiska, ale jednocześnie dostarczają na rynek ekologiczną żywność lub surowce do jej wytwarzania (Nachtman 2013).

Niniejsza publikacja ma na celu przedstawienie jednej z metod, które pozwalają oszacować potencjał towarowej produkcji ekologicznej i jej specjalizacji na określonym obszarze. Należy jednakże mieć na uwadze, że przybliżona tu metoda pozwala na teoretyczną ocenę potencjału towarowości gospodarstw, nie odnosząc się do faktycznego poziomu plonów ani realizowanej w latach poprzednich sprzedaży z konkretnego gospodarstwa.

\section{Metodologia szacowania potencjału towarowości gospodarstw ekologicznych}

Charakteryzując związki gospodarstwa rolnego z rynkiem, zwykło się używać kategorii produkcji towarowej, tj. wartości produkcji zbywanej poza gospodarstwo (Kulikowski 2013). Stopień towarowości według Romana Kulikowskiego i Jacka Szyrmera (1978) to odsetek produkcji przekazanej poza gospodarstwo lub sprzedanej w ogólnej produkcji gospodarstwa. Niemniej jednak taka metoda wymaga oparcia na danych rachunkowych, które nie są dostępne dla ogółu polskich gospodarstw rolnych. Szacowanie stopnia towarowości wymagałoby ponadto nie tylko znajomości danych o sprzedaży z gospodarstwa, ale także oszacowania wartości produkcji globalnej tego sektora. Brak obowiązku prowadzenia zapisów rachunkowych w gospodarstwach rolnych ogranicza, co do zasady, możliwości analityków i ekonomistów rolnych. Nie posiadając danych rachunkowych ze wszystkich gospodarstw ekologicznych, autorzy zadecydowali o wybraniu innej metody oznaczenia potencjału towarowego tych gospodarstw. Wykorzystano metodę analogiczną jak w przypadku wyznaczania progu towarowości gospodarstw rolniczych w Unii Europejskiej (Bocian, Cholewa, Tarasiuk 2017; Goraj 2008). Za wyborem tym przemawiał międzynarodowy charakter zastosowanej metody oraz możliwość regionalnego dopasowania wskaźników tzw. Standardowej Produkcji ${ }^{3}$ (Bocian,

3 Standardowa Produkcja (w skrócie z angielska SO - Standard Output) jest parametrem stosowanym we wszystkich krajach UE m.in. do wyboru próby unijnych gospodarstw towarowych, których dane służą do oceny sytuacji ekonomicznej europejskich rolników i są wykorzystywane przez decydentów w procesie kształtowania Wspólnej Polityki Rolnej. Wielkość SO wyznacza się na podstawie danych statystycznych 
Cholewa, Tarasiuk 2017). Przyjmując, że na potrzeby sprawozdawczości UE (danych FADN) graniczną wartością pozwalającą uznać gospodarstwo rolne za towarowe jest wytworzenie sumy Standardowej Produkcji o wartości 4000 EUR, uznano, że jako towarowe traktowane będą jedynie te gospodarstwa, których suma wartości Standardowej Produkcji przekroczy 16000 PLN $^{4}$.

Należy podkreślić, że w przyjętym algorytmie liczona jest potencjalna towarowość gospodarstwa. Obliczenia te nie informują o faktycznych związkach rolnika z rynkiem, a jedynie służą wskazaniu tych gospodarstw, które dysponują wystarczającym potencjałem (areałem lub wielkością stada), aby uzyskać sumę produkcji uznawaną według metodyki FADN dla danego kraju lub regionu za potencjalnie towarową. Za przyjęciem metody opartej na współczynnikach Standardowej Produkcji (SP) przemawia fakt, że są one wartościami przeciętnymi dla regionu (uwzględniają m.in. lokalną specyfikę cen i warunków pogodowych). Zarzutem wobec tej metody może być argument, że przeciętne regionalne współczynniki Standardowej Produkcji traktują jednakowo gospodarstwa ekologiczne i konwencjonalne.

Realna wydajność uzyskiwana z powierzchni bądź sztuki w gospodarstwie ekologicznym jest z zasady niższa niż w produkcji konwencjonalnej (Szeląg-Sikora, Kowalski 2012). Choć rachunek współczynników Standardowej Produkcji nie zawiera informacji o wartości dopłat, to jednak dopłaty przyznawane rolnikom ekologicznym (w swoim funkcjonalnym i systemowym założeniu) (Kisiel, Grabowska 2014; Szeląg-Sikora, Kowalski 2012) winny rekompensować straty powiązane z niższą wydajnością gospodarstw prowadzonych metodami ekologicznymi, stawiając tym samym gospodarstwa ekologiczne na równym poziomie dochodowym z gospodarstwami konwencjonalnymi (Kisiel, Grabowska 2014; Stalenga, Kuś 2007). Jak pokazują badania nad dochodowością gospodarstw ekologicznych, dzięki pozyskaniu dopłat do działalności operacyjnej rolnicy ekologiczni (we wszystkich grupach badanych gospodarstw) uzyskiwali dodatnie dochody, tym większe, im większe były zasoby ziemi upoważniające do pobierania dotacji (Nachtman 2013). Powyższa argumentacja pozwoliła na wykorzystanie tych samych wartości Standardowej Produkcji dla gospodarstw ekologicznych, które są wykorzystywane przy obliczeniach dla gospodarstw konwencjonalnych.

\footnotetext{
z 5 lat o przeciętnej produkcji uzyskiwanej z 1 ha uprawy lub 1 sztuki zwierząt (bez uwzględnienia wartości dopłat). Wskaźnik SO pozwala w przybliżeniu na podstawie powierzchni zasiewów i wielkości stada $\left(\sum\right.$ (powierzchnia ${ }^{*}$ współczynnik $)+\sum$ (zwierzęta* ${ }^{*}$ spółczynnik $\left.)\right)$ oszacować potencjalną wielkość produkcji w gospodarstwie. Użyte we wzorze współczynniki szacowane są na podsatwie danych regionalnych, dzięki czemu SO ujmuje pośrednio lokalne zróżnicowanie warunków produkcji.

4 Próg 16000 PLN został przyjęty dla większej przejrzystości prezentowanej metody oraz wyliczeń zgodnie z nią dokonanych.
} 
Według opracowanego przez Zygmunta Wojtaszka systemu klasyfikacji kierunków produkcji traktuje się gospodarstwo jako wyspecjalizowane bądź ukierunkowane, jeżeli udział wybranej działalności w sumie wartości produktów przekracza 40\% (Wojtaszek 1965). Idąc tym tropem, pośród wybranych do analiz gospodarstw autorzy dokonali obliczeń struktury sumy Standardowej Produkcji (SO), starając się rozeznać ukierunkowanie produkcyjne potencjalnie towarowych gospodarstw ekologicznych na określonym obszarze (w przypadku opisanych badań było to województwo podlaskie, w podziale na poszczególne powiaty).

\section{Rolnictwo ekologiczne w województwie podlaskim}

Do badań nad możliwością oceny towarowości gospodarstw ekologicznych wybrano województwo podlaskie. Za takim doborem przemawiało kilka przesłanek. Województwo podlaskie jest jednym z pierwszych w rankingach dotyczących rolnictwa ekologicznego w Polsce. Po województwie warmińsko-mazurskim zajmuje drugie w kraju miejsce pod względem liczby producentów ekologicznych (na koniec 2015 r. było ich 3296, co przekładało się na udział 14,3\% w kraju). Powierzchnia ekologicznych użytków rolnych na Podlasiu w 2016 r. przekraczała 46 tys. ha użytków po okresie konwersji i prawie 9,1 tys. ha w okresie konwersji (co plasowało województwo na trzecim miejscu w kraju). Łącznie w województwie podlaskim w 2017 r. na powierzchni 46,6 tys. ha gospodarzyło 2576 gospodarstw certyfikowanych ekologicznie, o bardzo różnej wielkości, strukturze i specjalizacji produkcji ${ }^{5}$.

Województwo podlaskie przodowało w produkcji wybranych ekologicznych produktów rolno-spożywczych, takich jak ziemniaki (1837 ha i 21,5 tys. ton 1 miejsce) i zboża (ponad 12 tys. ha i 23 tys. ton - drugie miejsce w kraju). W produkcji owoców i warzyw w odniesieniu do innych województw w kraju plasowało się odpowiednio na 7 i 11 pozycji.

W strukturze powierzchni badanych certyfikowanych gospodarstw dominowały pola uprawne (77\%), trwałe użytki zielone stanowiły $19,7 \%$, a sady $2,9 \%$. Zaznaczyć należy, że aż 47\% użytkowanej przez certyfikowane gospodarstwa ekologiczne powierzchni (w skali województwa) stanowiły grunty obsiane uprawami paszowymi.

Suma szacowanej Standardowej Produkcji ze wszystkich gospodarstw certyfikowanych ekologicznie w województwie wynosiła ok. 68,4 mln PLN na rok i w $90,1 \%$ pochodziła $\mathrm{z}$ produkcji roślinnej.

5 Dane według Raportu o stanie rolnictwa ekologicznego w Polsce $w$ latach 2015-2016 (GIJHARS 2017) oraz obliczenia własne na podstawie niepublikowanych informacji z Głównego Inspektoratu Jakości Handlowej Artykułów Rolno-Spożywczych (za 2017 r.). 
Powyższe przesłanki i charakterystyki Podlasia zadecydowały o wyborze województwa do badań.

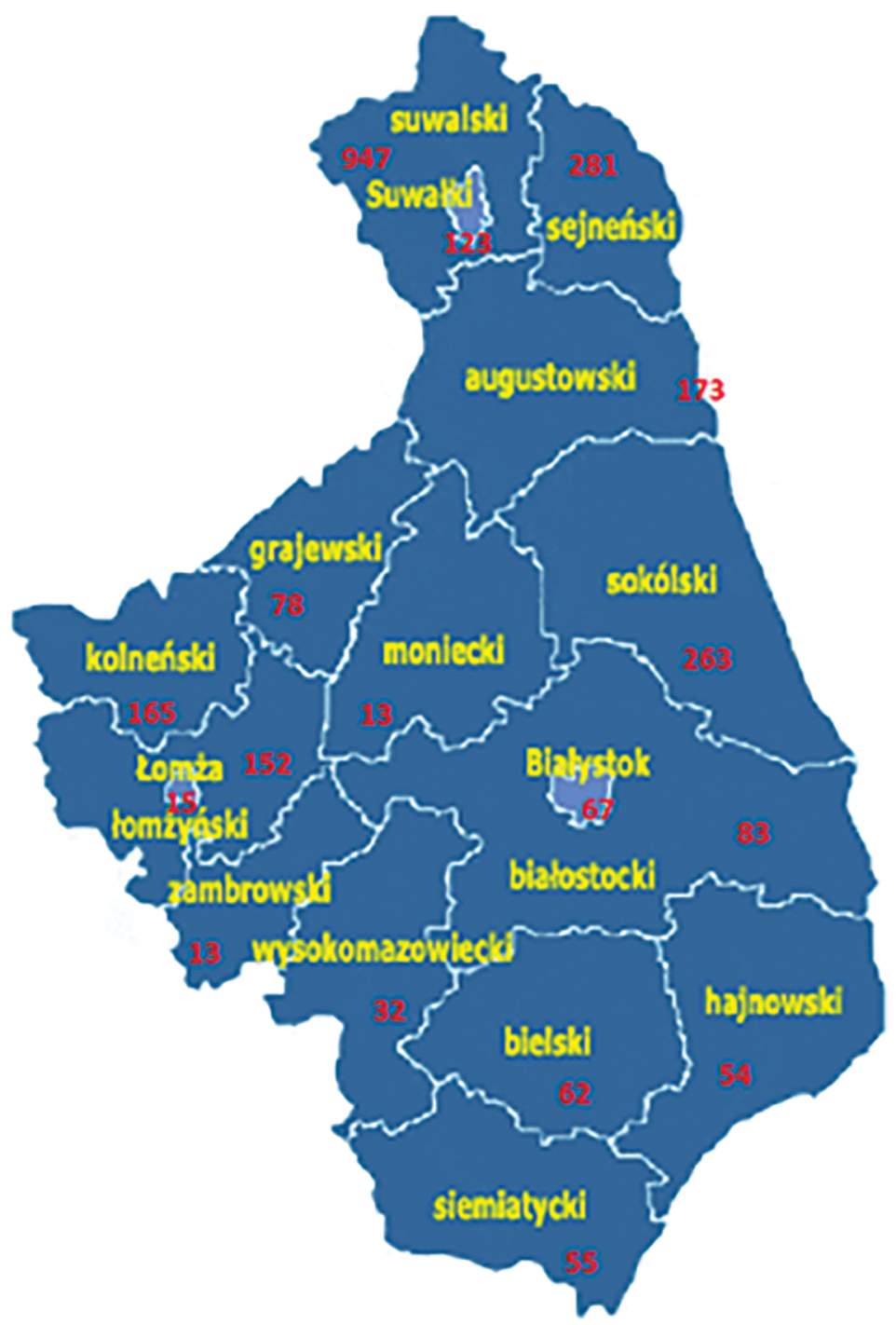

Rysunek 3. Przestrzenny rozkład liczby gospodarstw certyfikowanych z województwa podlaskiego w 2017 r. - podział na powiaty

Figure 3. Spatial pattern of farms in the Podlaskie voivodeship in 2017-by counties (poviats)

Źródło: opracowanie własne na podstawie danych GIJHARS 2017.

Source: Own study based on GIJHARS 2017. 


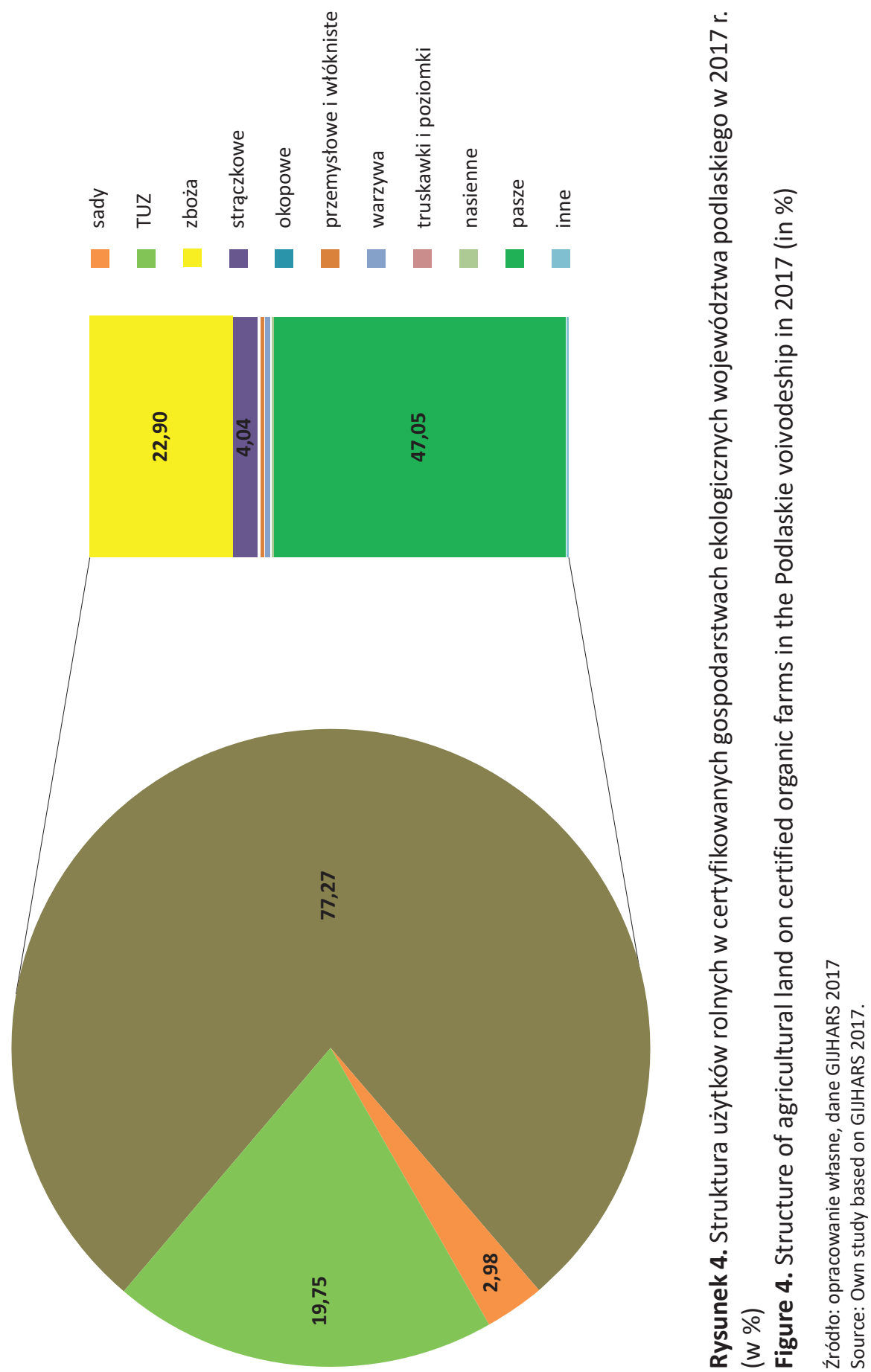




\section{Potencjał towarowości gospodarstw ekologicznych województwa podlaskiego}

Do oceny sytuacji gospodarstw ekologicznych w województwie podlaskim posłużono się niepublikowanymi wcześniej danymi Głównego Inspektoratu Jakości Handlowej Artykułów Rolno-Spożywczych (GIJHARS) z roku 2017. Autorzy na potrzeby poniższych analiz i zestawień zadecydowali o niewłączaniu do obliczeń gospodarstw na etapie przestawiania na rolnictwo ekologiczne (tzw. konwersji). Ten celowy zabieg pozwolił ograniczyć analizy do takich gospodarstw, które w pełni mogą korzystać z kontaktów z rynkiem, sprzedając certyfikowany produkt ekologiczny.

Zapis prawny dopuszcza, aby w gospodarstwach już certyfikowanych występowała powierzchnia upraw dopiero podlegająca konwersji w celu zwiększania użytkowanego przez nie areału. Dlatego jedyną uwzględniona w obliczeniach tego opracowania powierzchnią podlegająca konwersji jest powierzchnia użytkowana przez już certyfikowane gospodarstwa ekologiczne. Powierzchnia gospodarstw dopiero starających się o certyfikaty nie podlegała analizie w ramach niniejszego badania.

Wykorzystując powyżej opisaną metodologię oraz bazując na danych GIJHARS z 2017 r. o areale zasiewów i wielkości stad utrzymywanych w certyfikowanych gospodarstwach ekologicznych województwa podlaskiego, a także przyjmując (będące wskaźnikami średnimi z okresu 2011-2015) wskaźniki Standardowej Produkcji dla regionu FADN Mazowsze i Podlasie (Bocian, Cholewa, Tarasiuk 2017), dla każdego z badanych certyfikowanych gospodarstw wyznaczono sumę Standardowej Produkcji.

Z 2576 gospodarstw posiadających certyfikaty ekologiczne w województwie podlaskim, na podstawie zaewidencjonowanego w GIJHARS areału upraw i wielkości stada, zgodnie z wyżej opisaną metodą za potencjalnie towarowe uznano 1068 gospodarstw.

Jednakże analizie poddano także strukturę produkcji uznanej za potencjalnie towarową. Szczególną uwagę poświęcono gospodarstwom wyspecjalizowanym $\mathrm{w}$ produkcji pasz - tj. produktu rolnego zwyczajowo uznawanego za nietowarowy. Rachunek sumy Standardowej Produkcji z produkcji roślinnej zawiera bowiem powierzchnię trwałych użytków zielonych (łąk i pastwisk), a także pasz na gruntach ornych. Pasze objętościowe co do zasady uznawane są za produkt nietowarowy, jednakże postępująca specjalizacja i koncentracja produkcji zwierzęcej oraz wahania klimatyczno-pogodowe powodują, że pomimo trudności transportowych w ostatnich latach pasze objętościowe lokalnie również podlegały obrotowi towarowemu - jest to zagadnienie szczególnie istotne w odniesieniu do dynamicznie 
rozwijającej się w województwie podlaskim ekologicznej produkcji mleczarskiej i jako takie nie mogło zostać pominięte w niniejszej analizie.

Trudnością w prowadzonej analizie było rozgraniczenie gospodarstw, w których rośliny paszowe znajdują nabywcę lub są spasane przez zwierzęta, od tych gospodarstw, które zaewidencjonowany areał upraw paszowych utrzymują nie tyle w celach produkcyjnych, co jedynie dla pozyskania dopłat. Przepisy dotyczące dopłat do produkcji ekologicznej przed $2014 \mathrm{r}$. nie wymagały powiązania uprawy roślin paszowych z faktem posiadania zwierząt - okoliczność ta skutkowała częstymi przypadkami uprawy roślin paszowych jedynie dla pozyskania dodatkowych dopłat (rozpowszechniało się zjawisko tzw. ekologicznych trawnikowców) (Jasiński, Michalska, Śpiewak 2013). W analizowanej na potrzeby niniejszego opracowania ewidencji GIJHARS gospodarstw ekologicznych z 2017 r. mogą pozostawać jeszcze gospodarstwa korzystające z rozwiązania prawnego sprzed 2014 r. Należy mieć także na uwadze, że przepisy i restrykcje dotyczące ekologicznego chowu zwierząt często skutkują sytuacją, w której gospodarstwo certyfikuje produkcję roślinną, natomiast utrzymywane w nim zwierzęta formalnie traktowane są jako konwencjonalne. Skorzystanie z takiego rozwiązania umożliwia rolnikowi prowadzącemu ekologiczną uprawę roślin stosowanie antybiotyków w chowie zwierząt w obrębie tego samego gospodarstwa. Istniejąca ewidencja GIJHARS nie pozwala jednakże na wyselekcjonowanie takich przypadków.

Mając na uwadze wrażliwość danych dotyczących rynkowego przeznaczenia produkowanych pasz, autorzy starali się ten aspekt uwzględniać, prowadząc równolegle analizę dla próby gospodarstw pomniejszonej liczebnie o jednostki, w których areale dominowały rośliny paszowe przy jednoczesnym braku ekologicznej produkcji zwierzęcej.

Z próby 1068 gospodarstw przed przeprowadzeniem pogłębionej analizy wykluczono gospodarstwa, w których w strukturze sumy Standardowej Produkcji udział pasz uprawianych na gruntach ornych przekraczał $40 \%$ przy jednoczesnym braku utrzymywanych zwierząt. Po tym zabiegu pozostało w próbie 768 obiektów. W dalszej części tekstu autorzy analizować będą obie próby (1068 i 768 gospodarstw).

Uznane za potencjalnie towarowe 1068 gospodarstwa użytkowały w $2017 \mathrm{r}$. łącznie 26,4 tys. ha, co pozwalałoby na uzyskanie w sumie ok. $58 \mathrm{mln}$ PLN Standardowej Produkcji rocznie na województwo, z czego ponad 89\% stanowiła produkcja roślinna (tabela 1).

Należy w tym miejscu podkreślić, że aż 899 gospodarstw z tej próby (wg ewidencji GIJHARS) nie utrzymywało ekologicznych zwierząt. Łącznie w badanych 1068 gospodarstwach ekologicznych utrzymywano 1671 sztuk bydła (w tym 602 ekologiczne krowy mleczne), 1118 owiec oraz 3828 kur niosek (tabela 2). 
Rejonem wyspecjalizowanym w chowie bydła ekologicznego był powiat suwalski, w którym utrzymywano ponad $60 \%$ bydła ekologicznego całego województwa. Również $\mathrm{w}$ tym powiecie odnotowano jedne $\mathrm{z}$ najwyższych $\mathrm{w}$ województwie udziały roślin paszowych w strukturze zasiewów. Należy podkreślić, że w powiecie tym utrzymywane było niemal 30\% wszystkich ekologicznych krów mlecznych z województwa podlaskiego. Dla porównania udział kolejnych pod względem liczby ekologicznych krów mlecznych w województwie powiatach łomżyńskim i bielskim wynosił odpowiednio $20 \%$ i $12 \%$.

Powiat suwalski wraz z powiatem augustowskim przodowały również w produkcji kur niosek ekologicznych, łącznie w tych dwóch powiatach utrzymywano $40 \%$ wszystkich niosek ekologicznych z województwa.

Ekologiczna produkcja owczarska skupiona była głównie w powiatach hajnowskim i sokólskim (powiaty te skupiły ponad $2 / 3$ pogłowia objętych certyfikatem ekologicznym w województwie podlaskim owiec - przy czym nie miało to konsekwencji w zwiększeniu udziału roślin paszowych w zasiewach. Obserwacja ta oznacza, że chów owiec opierał się głównie na paszach pozyskanych z trwałych użytków zielonych (TUZ).

Analiza struktury składowych areałów produkcji roślinnej (tabele 3 i 4) wskazuje na znaczny udział upraw paszowych na gruntach ornych. O ile w skali wszystkich (2576) certyfikowanych gospodarstw województwa zasiewy pasz pokrywały $47 \%$ powierzchni, o tyle w próbie (1068) gospodarstw uznawanych za towarowe udział ten wynosił około $38 \%$ w skali całego województwa. Główną składową areału gruntów ornych przeznaczonych pod zasiewy roślin paszowych stanowiły zasiewy traw.

Jedynie 562 z 1068 gospodarstw uznanych za towarowe nie posiadało żadnego areału gruntów ornych obsianego trawami. Dla porównania w 30 gospodarstwach z 1068 udział traw na gruntach ornych wynosił ponad 90\%, a jedynie jedno z tych 30 gospodarstw utrzymywało bydło, podczas gdy pozostałe 29 nie posiadało wcale produkcji zwierzęcej (12 z tych 30 gospodarstw znajdowało się w powiecie suwalskim, a sześć w powiecie miasto Suwałki). Właśnie ten fakt skłonił autorów do równoległego prowadzenia analizy dla próby gospodarstw towarowych „oczyszczonej” z gospodarstw nieposiadających zwierząt przy równoczesnym wyspecjalizowaniu w produkcji upraw paszowych. Oczyszczona próba, jak nadmieniono wyżej, liczyła 768 gospodarstw. 


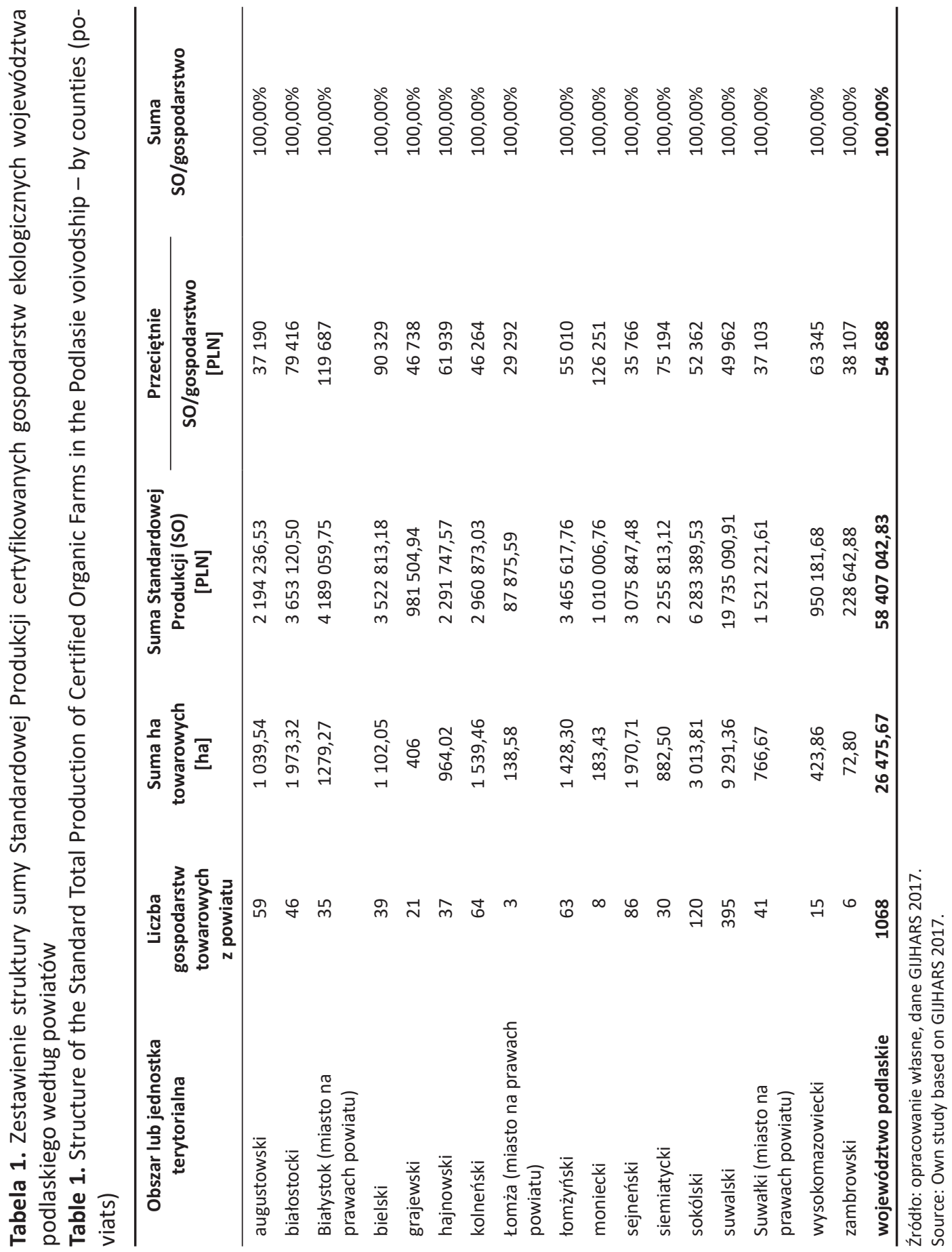




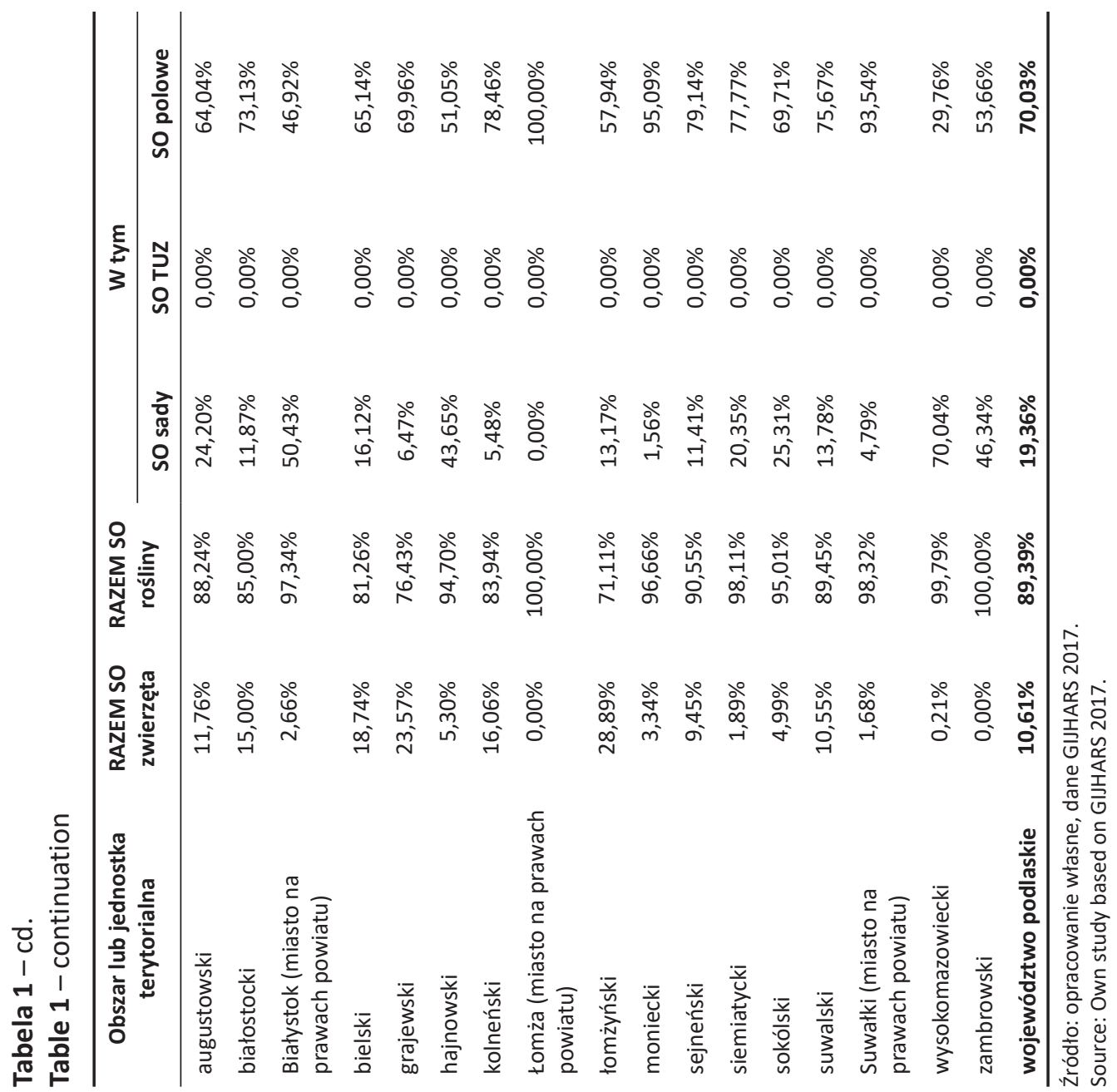




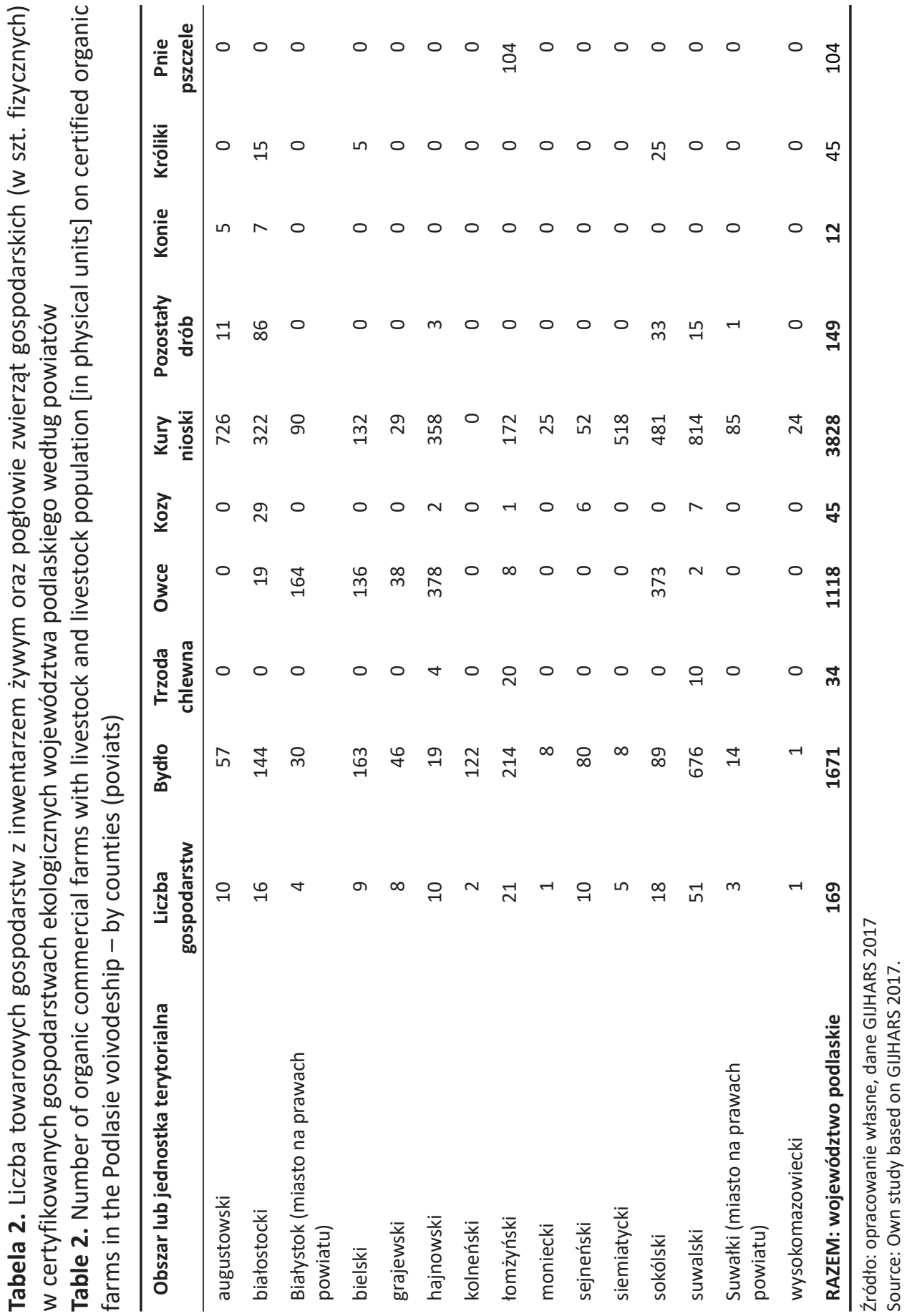




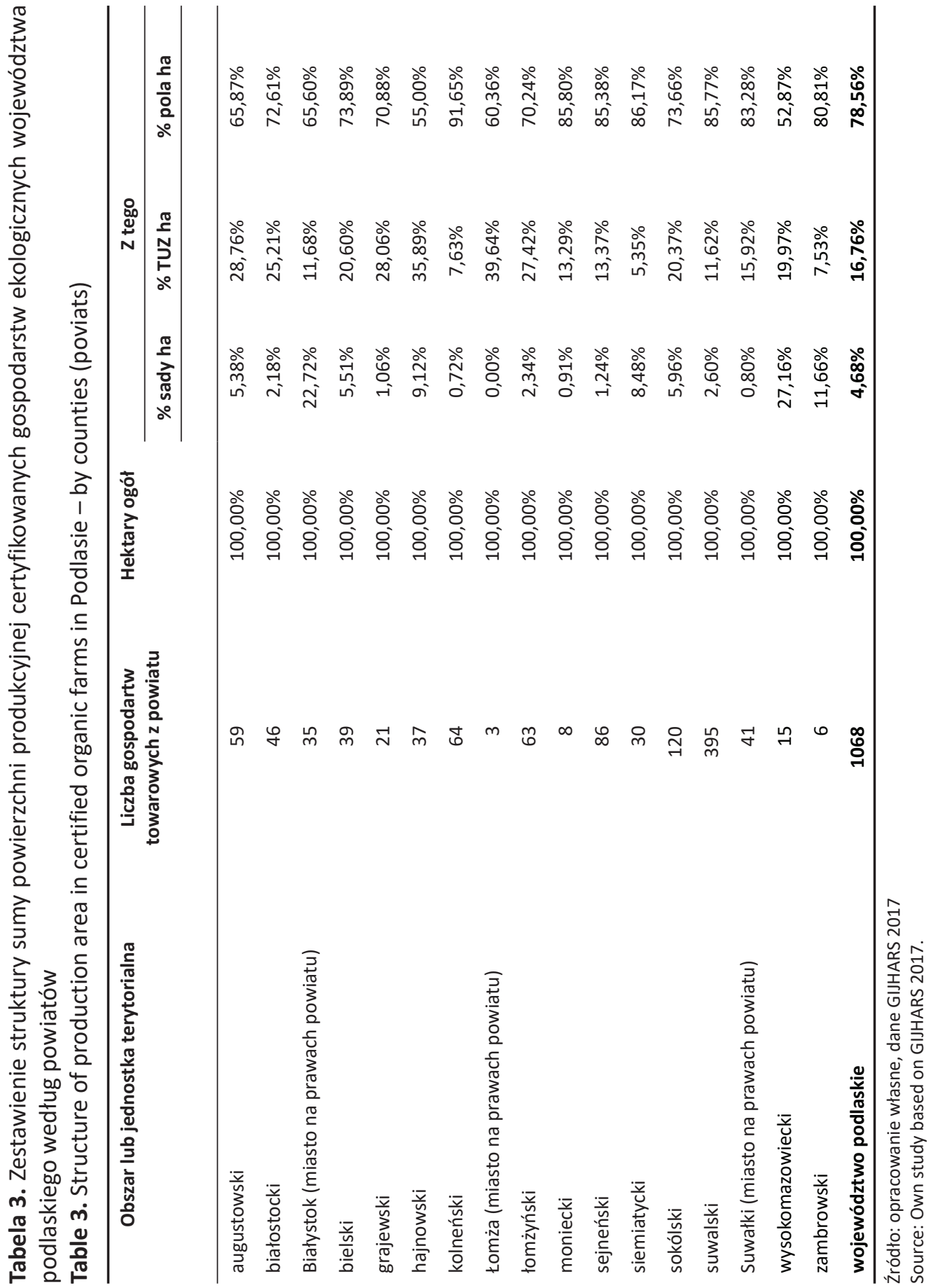




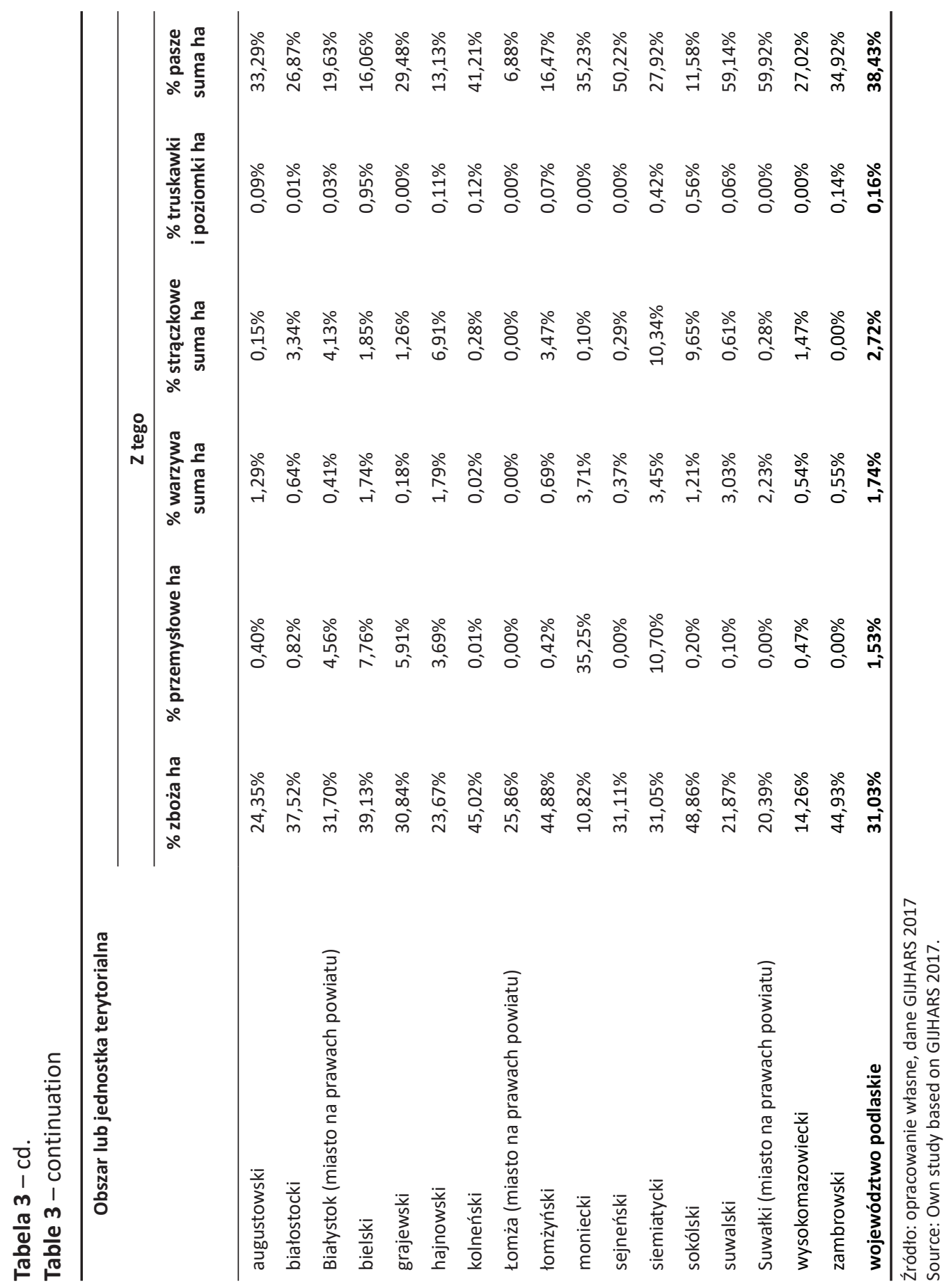


Tabela 4. Przeciętny udział powierzchni obsianej trawami na gruntach ornych (GO) w powierzchni użytków rolnych (UR) towarowego gospodarstwa ekologicznego według powiatów (próba 1068) (w \%)

Table 4. Average share of grassland area on arable land in agricultural areas of organic farms - by counties (poviats) (sample size: 1068 farms) (in \%)

\begin{tabular}{lc}
\hline \multicolumn{1}{c}{ Obszar lub jednostka terytorialna } & Średni udział traw w areale ogółem \\
\hline augustowski & 20,32 \\
białostocki & 6,77 \\
Białystok (miasto na prawach powiatu) & 8,31 \\
bielski & 1,27 \\
grajewski & 1,26 \\
hajnowski & 0,00 \\
kolneński & 4,68 \\
Łomża (miasto na prawach powiatu) & 1,12 \\
łomżyński & 3,10 \\
moniecki & 21,15 \\
sejneński & 26,40 \\
siemiatycki & 2,83 \\
sokólski & 0,60 \\
suwalski & 29,01 \\
Suwałki (miasto na prawach powiatu) & 42,87 \\
wysokomazowiecki & 1,99 \\
zambrowski & 14,79 \\
województwo podlaskie & 17,14 \\
\hline
\end{tabular}

Źródło: opracowanie własne, dane GIJHARS 2017

Source: Own study based on GIJHARS 2017.

W wyodrębnionej próbie 786 towarowych gospodarstw certyfikowanych udział sadów w powierzchni użytków rolnych stanowił 6\%, trwałych użytków zielonych $18 \%$, gruntów ornych zaś $76 \%$. W zasiewach na gruntach ornych dominowały zboża (38\%) oraz uprawy materiału rozmnożeniowego - nasiona i sadzonki (25\%). $\mathrm{Na}$ trzecim miejscu uplasowały się uprawy roślin strączkowych, które zajmowały $6 \%$ powierzchni UR. 


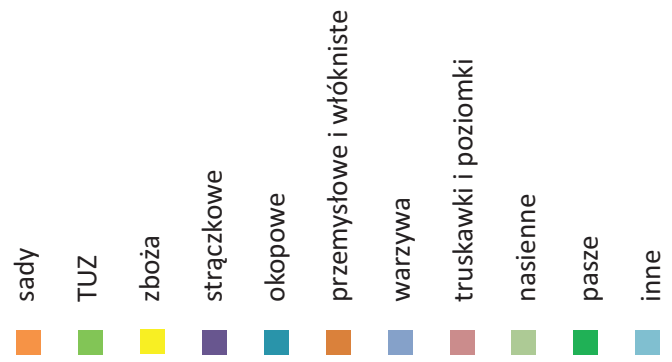

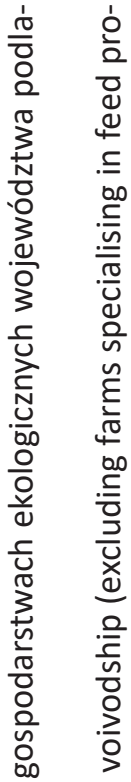

บ

त $3 \overline{0}$

웜

芒芒

产: :示

들 है

ㅇำ

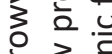

$\frac{10}{5} \frac{1}{5}$

उ 닝

3 त $\frac{1}{0}$

บิ

든 $\frac{\bar{d}}{\sqrt[0]{0}}$

3 号苍

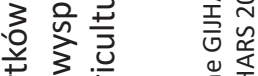

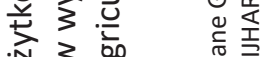

. त 30000

तथ

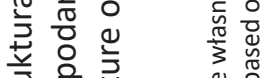

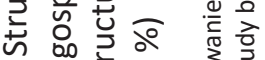

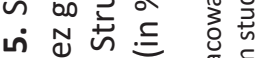

ะ气 ம

닥 인 은

$\stackrel{\infty}{\sim}$

童

ㅎํำ 


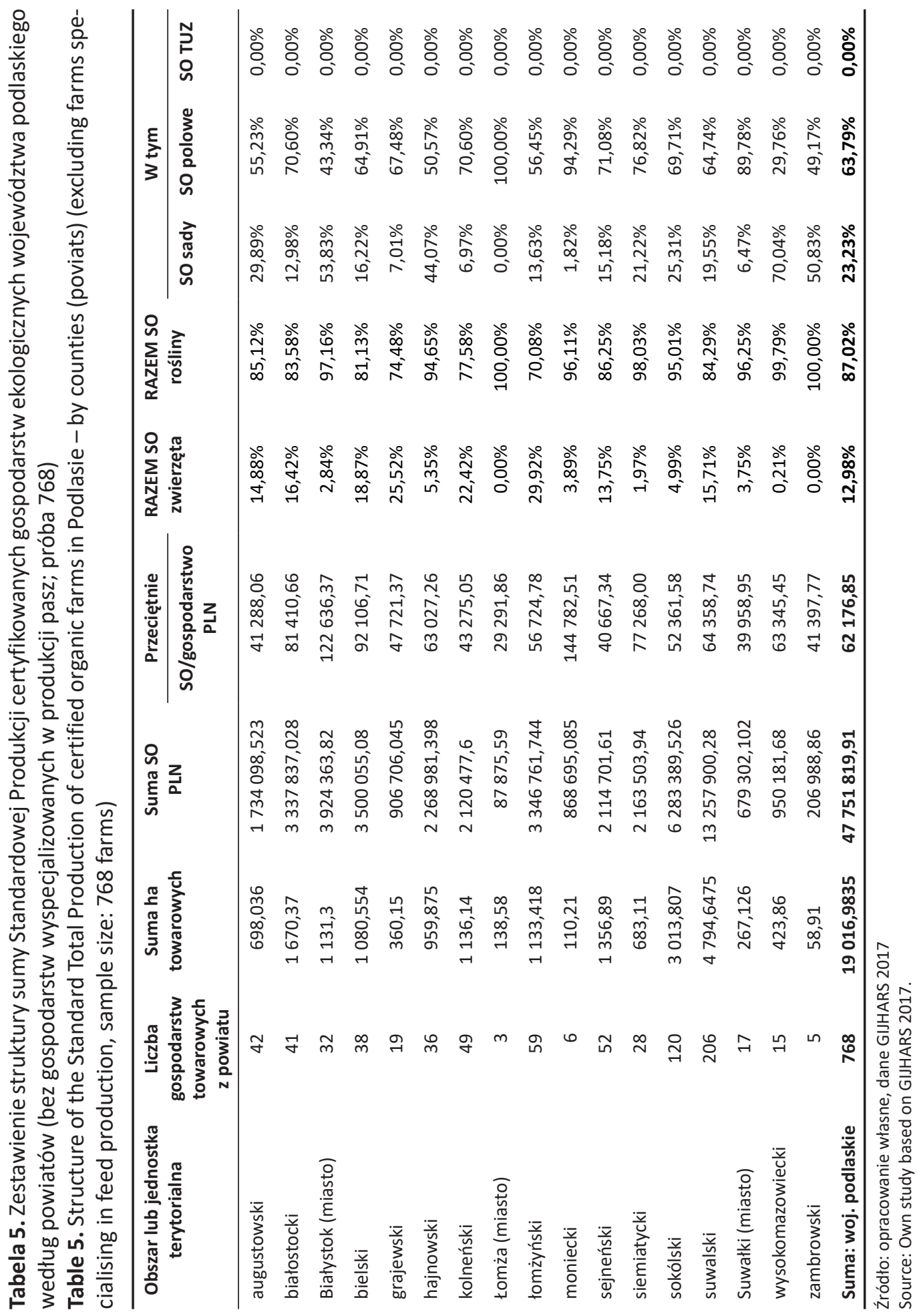


Wyodrębnione towarowe gospodarstwa ekologiczne użytkowały łącznie ponad 19 tys. ha i uzyskały w sumie $47 \mathrm{mln}$ PLN Standardowej Produkcji rocznie, z czego 87\% stanowiła produkcja roślinna. Dominującym kierunkiem $(63,79 \%)$ były uprawy polowe. Na tle całego województwa wyróżniały się cztery powiaty wyspecjalizowane w produkcji sadowniczej (wysokomazowiecki, miasto Białystok, zambrowski, hajnowski).

\section{Podsumowanie}

Od dekady ponad 20 tysięcy gospodarstw rolnych w Polsce jest każdego roku certyfikowanych na okoliczność spełniania wymogów rolnictwa ekologicznego. Gospodarstwa te z jednej strony charakteryzują się stosowaniem metod produkcji nieszkodliwych dla środowiska naturalnego, $\mathrm{z}$ drugiej strony powinny dostarczać konsumentom certyfikowanych, ekologicznych produktów żywnościowych. Ze względu na specyfikę traktowania fiskalnego gospodarstw rolnych w Polsce niezwykle trudno jest określić wartość i skalę zarówno rzeczywistej, jak i choćby potencjalnej produkcji ekologicznej żywności, która jest lub mogłaby być wytwarzana w naszym kraju. Nie sprzyja temu także system dopłat, który nie premiuje rolników prowadzących towarową produkcję ekologicznej żywności - przez co trudno jest oddzielić tych, którzy koncentrują się wyłącznie na walorach środowiskowych produkcji ekologicznej, od tych, którzy dostarczają ekologiczną żywność lub ekologiczne surowce na rynek.

Jednocześnie rolnictwo ekologiczne wymieniane jest w wielu publikacjach naukowych jako potencjalna nisza rozwojowa, która może stać się opłacalną, choć nie masową, alternatywą dla produkcji żywności konwencjonalnej (Golik, Żmija 2017; Domagalska, Buszkowska 2015). Niebagatelny jest także wpływ rolnictwa ekologicznego na rozwój lokalny (Jasiński, Michalska, Śpiewak 2013), przez co jest ono przedstawiane w kluczowych polskich dokumentach strategicznych (zob. Strategia na rzecz Odpowiedzialnego Rozwoju...) jako szansa rozwojowa dla części terenów wiejskich. Mając na uwadze powyższe, istotne wydaje się posiadanie umiejętności określania skali towarowej produkcji ekologicznej.

Autorzy niniejszego tekstu opracowali metodę pozwalającą w stosunkowo prosty sposób i przy użyciu dotychczas wykorzystywanego narzędzia (FADN) szacować potencjał ekologicznej produkcji i jej specjalizacji na określonym obszarze. Należy jednakże mieć na uwadze, że przedstawiona tu metoda pozwala na teoretyczną ocenę potencjału towarowości gospodarstw, nie odnosząc się do faktycznego poziomu plonów ani realizowanej w latach poprzednich sprzedaży $z$ konkretnego gospodarstwa. Zaproponowane rozwiązanie jest na tyle elastyczne, że może być dowolnie modyfikowane, a punkty referencyjne dowolnie dopasowywane 
do specyfiki danego kraju, regionu, a także uwarunkowań produkcyjnych - czego przykładem jest zaprezentowane powyżej wyliczenie szacunkowego potencjału towarowych gospodarstw ekologicznych na Podlasiu dokonane zarówno w podziale geograficznych, jak i branżowym, przy jednoczesnym oddzieleniu gospodarstw wyspecjalizowanych w towarowej produkcji pasz.

\section{Bibliografia}

Bocian M., Cholewa I., Tarasiuk R. (2017). Współczynniki Standardowej Produkcji „2013” dla celów Wspólnotowej Typologii Gospodarstw Rolnych. Warszawa: Instytut Ekonomiki Rolnictwa i Gospodarki Żywnościowej - PIB.

Brodzińska K. (2014). Rolnictwo ekologiczne - tendencje i kierunki zmian. Zeszyty Naukowe Szkoły Głównej Gospodarstwa Wiejskiego w Warszawie, Problemy Rolnictwa Światowego, 14 (29), 3, http://yadda.icm.edu.pl/yadda/element/bwmeta1.element.agro-b972d3aef25c-4771-bab2-ed21cc6a27b4/c/27-36.pdf (dostęp: 30.04.2019).

Domagalska J., Buczkowska M. (2015). Rolnictwo ekologiczne - szanse i perspektywy rozwoju. Problemy Higieny i Epidemiologii, 96 (2), 373-375, http://www.phie.pl/pdf/ phe-2015/phe-2015-2-370.pdf (dostęp: 28.02.2019).

Drygas M., Bańkowska K., Nurzyńska I., Wycech K., Gradka I., Lesisz T. (2017). Uwarunkowania ekonomiczne i społeczne rozwoju rolnictwa ekologicznego w Polsce (raport $z$ badań). Warszawa: Instytut Rozwoju Wsi i Rolnictwa PAN. http://www.irwirpan. waw.pl/polski/Raport_Uwarunkowania_ekonomiczne_i_spoleczne_rozwoju-2007. pdf (dostęp: 30.04.2019).

EKES (2017). Opinia Europejskiego Komitetu Ekonomiczno-Społecznego „Możliwe przekształcenie wspólnej polityki rolnej" (Opinia rozpoznawcza). Dz.Urz. UE 2017/C 288/02. https://eur-lex.europa.eu/legal-content/PL/TXT/PDF/?uri=CELEX:52017AE0955\&fr om=ES (dostęp: 29.04.2019).

EKR (2017). Opinia Europejskiego Komitetu Regionów - WPR po 2020 r. Dz.Urz. UE 2017/C $342 / 02$.

GIJHARS (2017). Raport o stanie rolnictwa ekologicznego w Polsce w latach 2015-2016. Warszawa: Główny Inspektorat Jakości Handlowej Artykułów Rolno-Spożywczych.

Golik D., Żmija D. (2017). Rolnictwo ekologiczne i perspektywy jego rozwoju w Polsce w świetle doświadczeń Unijnych. Zeszyty Naukowe Uniwersytetu Ekonomicznego w Krakowie, 1 (961), https://zeszyty-naukowe.uek.krakow.pl/article/viewFile/1160/933 (dostęp: 28.04.2019).

Goraj L. (2008). FADN i Polski FADN (Sieć danych rachunkowych gospodarstw rolnych $i$ system zbierania $i$ wykorzystywania danych rachunkowych $z$ gospodarstw rolnych). Warszawa: Instytut Ekonomiki Rolnictwa i Gospodarki Żywnościowej - PIB.

IFOAM. https://www.ifoam.bio/en/organic-landmarks/definition-organic-agriculture, 25.10.2017 (dostęp: 30.04.2019).

Jasiński J., Michalska S., Śpiewak R. (2013). Rolnictwo ekologiczne czynnikiem rozwoju lokalnego - analiza wybranych przypadków. Warszawa: Instytut Rozwoju Wsi i Rolnictwa 
PAN.http://www.irwirpan.waw.pl/polski/IRWiR_PAN_raport_Rolnictwo_ekologiczne_czynnikiem_rozwoju_lokalnego.pdf (dostęp: 30.04.2019).

Kisiel R., Grabowska N. (2014). Rola dopłat unijnych w rozwoju rolnictwa ekologicznego w Polsce na przykładzie województwa podlaskiego. Woda - Środowisko - Obszary Wiejskie, 14 (3 [47]), 61-73.

Komisja Europejska (2016). Grupa zadaniowa ds. rynków rolnych przedstawia zalecenia dotyczące rolników w łańcuchu dostaw żywności. Komunikat prasowy, Bruksela, 14.11.2016. https://ec.europa.eu/info/food-farming-fisheries/key-policies/common-agricultural-policy/market-measures/unfair-trading-practices i http://europa.eu/rapid/press-release_IP-16-3658_pl.pdf (dostęp: 28.04.2019).

Kulikowski R. (2013). Produkcja i towarowość rolnictwa w Polsce. Przemiany i zróżnicowanie przestrzenne po II wojnie światowej. Warszawa: Instytut Geografii i Przestrzennego Zagospodarowania PAN im. Stanisława Leszczyckiego.

Kulikowski R., Szyrmer J. (1978). Produktywność, towarowość i struktura produkcji rolnej. W: J. Kostrowicki (red.). Przemiany struktury przestrzennej rolnictwa Polski 1950-1970 (s. 360-427). Wrocław: Zakład Narodowy im. Ossolińskich - Wydawnictwo.

Lisowska B. (2010). Plantacje chwastów za unijne pieniądze. Gazeta Prawna, 15.10. https:// biznes.gazetaprawna.pl/artykuly/458729,plantacje-chwastow-za-unijne-pieniadze.html (dostęp: 28.04.2019).

Ministerstwo Rolnictwa i Rozwoju Wsi (2018). Ramowy Plan Działań dla Żywności i Rolnictwa Ekologicznego w Polsce na lata 2014-2020 (zaktualizowany 5 czerwca 2018 r.). Warszawa.

Nachtman G. (2013). Dochodowość gospodarstw ekologicznych a wielkość użytków rolnych. Roczniki Ekonomii Rolnictwa i Rozwoju Obszarów Wiejskich, 100 (1).

Nowogródzka T., Podstawka M., Szarek S. (2013). Towarowość a sytuacja produkcyjno-ekonomiczna gospodarstw ekologicznych w Polsce. Wieś i Rolnictwo, 2 (159), 157-168.

Poczta W., Sadowski A., Czubak W., Matyka M., Drygas M., Skórnicki H. (2017). Reforma Wspólnej Polityki Rolnej po 2020 roku. KRIR Materiały konferencyjne, październik. http://www.krir.pl/files/dopobrania/2017_09_24_CA\%C5\%81O\%C5\%9A\%C4\%86_3. pdf (dostęp: 23.04.2019).

Stalenga J., Kuś J. (2007). Możliwości rozwoju rolnictwa ekologicznego w Polsce. Studia i Raporty IUNG-PIB, 6, 9-17.

Strategia na rzecz Odpowiedzialnego Rozwoju do roku 2020 (z perspektywa do 2030 r.). Warszawa. https://powietrze.gios.gov.pl/pjp/documents/download/102570 (dostęp: 23.04.2019).

Styczek-Kuryluk M. (2016). Kolejny spadek liczby eko gospodarstw i powierzchni eko użytków rolnych. Eko Arka, lipiec. http://ekoarka.com.pl/kolejny-spadek-liczby-eko-gospodarstw-i-powierzchni-eko-uzytkow-rolnych/ (dostęp: 30.04.2019).

Szeląg-Sikora A., Kowalski J. (2012). Efektywność rolniczej produkcji ekologicznej w zależności od kierunku produkcji gospodarstwa rolnego. Inżynieria Rolnicza, 1 (4 [139]). https://ir.ptir.org/artykuly/pl/139/IR(139)_3296_pl.pdf (dostęp: 29.04.2019).

Śmigiel S., Miączyński P., Kostrzewski L. (2009). Kokosy na orzechach. Gazeta Wyborcza, 31.07. http://wyborcza.pl/1,155287,6878873,Kokosy_na_orzechach.html?disableRedirects=true (dostęp: 29.04.2019). 
Wojtaszek Z. (1965). Kryteria i mierniki klasyfikacji gospodarstw indywidualnych według kierunków produkcji. Roczniki Nauk Rolniczych. Seria G, 78 (1/1), 69-98.

Zarudzki R., cyt. za http://www.portalspozywczy.pl/technologie/wiadomosci/ministerstwo-rolnictwa-bedzie-wspieralo-rolnictwo-ekologiczne,166003.html (dostęp: 23.04.2019).

\title{
An Evaluation of the Economic Potential of Organic Farms in Podlaskie Voivodeship
}

\begin{abstract}
European society is rapidly expanding its interest in the environmental issues. It is also reflected in the changes in consumer attitudes. The conscious consumers looking for high quality food pay particular attention to the transparency of its production (tracebility) and are interested in its geographical origin. Organic farming products are one of the possible answers to the emerging and dynamically developing consumer trends.

In polemics on the future development of organic farming, the range of support dedicated to the organic sector is a very common issue. Organic farms on the one hand contribute to the production of environmental public goods, on the other hand are the production sites of high quality food. It is therefore important not only to analyse the dynamics of changes in the organic areas and the number of farms with the relevant certificate, but first of all to analyse the production potential of the organic sector. In a relatively simple way and based on previously used tools (FADN Farm Accountancy Data Network), the authors have developed a method that estimates both the potential of organic production and its specialisation in a given area.
\end{abstract}

Keywords: organic farming, production volume of organic food, organic production potential. 